\title{
E-Learning rendszer és elektronikus tananyagfejlesztés a Könyvtári Intézetben
}

\author{
Szepesi Judit \\ Országos Széchényi Könyvtár, Könyvtári Intézet \\ szepesi.judit@oszk.hu
}

We would like to present the plans of an e-learning system for the Hungarian Library Institute. Within the OKR project of the National Széchényi Library we develop also electronic training materials for librarians.

Keywords: e-learning, e-learning system, blended learning, Hungarian Library Institute, professional training.

\section{Bevezetö}

A teljes életpályára kiterjedő képzés igénye és az oktatási médiumok (nyomtatott, elektronikus) változatainak fejlödése révén egyre szélesebb körben alkalmazzák a hagyományos oktatási formák mellett az elektronikus eszközökkel támogatott blended képzéseket. E képzési forma rugalmas módon támogatja a munka melletti tanulást, figyelembe véve a képzésben résztvevők eltérö felkészültségét, tanulási szokásait és időbeosztását.

Az Országos Széchényi Könyvtár, az Országos Könyvtári Rendszer projektjének részeként a Könyvtári Intézet távoktatási rendszerének

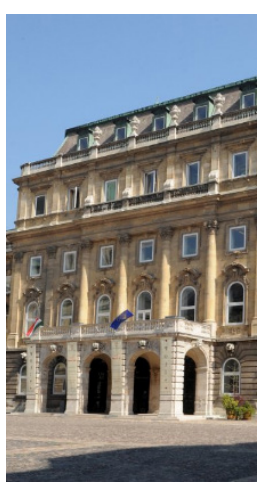
a megújitásán és multimédiás tananyagok fejlesztésén dolgozik.

A 2018-as Networkshop-on beszéltünk elöször a fejlesztési tervekröl, jelen összefoglaló célja, hogy az azóta történt munkát bemutassa.

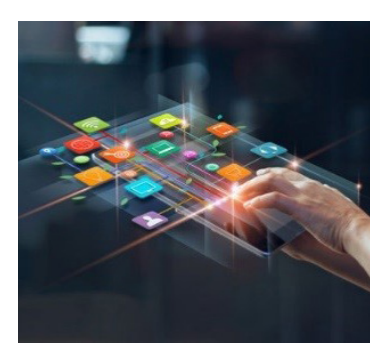

\section{E-learning rendszer}

Jelenleg az e-learning rendszerünk közbeszerzési folyamata még nem zárult le, ezért a terveket csak röviden - a lényeges elemeket kiemelve - mutatom be.

Tervezési munkánk során meg kellett állapítanunk, hogy az e-learninghez kapcsolódó szóhasználat és a meghatározások ellentmondásokat, illetve néhol átfedéseket mutatnak. Ez föleg abból adódik, hogy magát az e-learning rendszert sokszor azonositják azzal a szoftverrel, alkalmazással, keretrendszerrel, amely támogatja az online oktatást, a tanulást és az oktatásszervezési feladatokat. Véleményünk szerint a tanulási folyamatokat támogató keretrendszer csak egy eleme lehet az e-learning környezetnek, és mellette más online és/vagy offline alkalmazások is szükségesek.

A projekt keretén belüli tervezés során a tanulási környezet kialakitása mellett további modulokat is tervezünk, amelyek megkönnyitik az oktatásszervezök számára az egységes adatkezelést, átláthatóvá teszik a dokumentációkat. 
A tervezés során fontosnak tartottuk a szabványok használatát, ezzel biztosítva a rendszer átjárhatóságát.

\section{Célkitüzésünk}

A fejlesztési feladat célja olyan weben elérhető e-learning portál (szolgáltató rendszer) kialakitása, amely támogatja a Könyvtári Intézet továbbképzési tevékenységéböl fakadó adminisztrációs és dokumentációs feladatok ellátását. Újdonság lesz, hogy a tervek szerint az Országos Széchényi Könyvtár belső képzéseit is támogatni fogja a portál. A rendszer használatával lehetőséget szeretnénk adni más könyvtáraknak is, hogy - megfelelö felkészités után - saját szakmai oktatási tevékenységüket ezen keresztül szervezhessék.

Az oktatási tartalmak egy böngészőn keresztül lesznek hozzáférhetők. A tanulási folyamatokhoz web 2.0-ás környezetet hozunk létre. amely alkalmazásaival közvetlenül és közvetetten is támogatja a kapcsolatok kiépítését és a közösségi tanulás folyamatát. A tanulási környezetben mini blogolási lehetöséget kinálunk, google alkalmazásokat építünk be (Pl. Google calendar eseményértesitővel).

Az elkészült tananyagokat egy tananyagtárban helyezzük el, ahol gondoskodunk a tananyag-elemek és a tananyagok feldolgozásáról, tárolásáról. Elképzelhetőnek tartjuk egy nyilt forráskódú dokumentumkezelő vagy tartalomkezelő rendszer beépitését a rendszerbe (pl.: Liferay, Dispace).

\section{A tervezett rendszer elemei}

- webes szolgáltató felület

Az e-learning portál egy szolgáltató felület, amely mögött moduláris felépítésü programrendszer támogatja az oktatásszervezési, tanulási, tanulás-irányítási, oktatási feladatok elvégzését, valamint a digitális tananyagtár kezelését.

- oktatásszervezési modul

Háttéradatbázisok és ürlapok segítségével teljes körüen képes ellátni a képzések (OKJ-s képzés, akkreditált tanfolyamok, nem akkreditált belső képzések) szervezéséhez szükséges adminisztrációs és dokumentációs feladatokat.

- tanulási és oktatási folyamatokat támogató modul

A tanulásirányítási oldal olyan eszközöket nyújt, amelyek segitségével könnyen megtervezhető és összeállítható egy továbbképzés tartalma, a tanfolyamok lebonyolíthatók, a tanulási folyamatok nyomon követhetök, ellenörizhetők. Törekszünk arra, hogy a tananyagok mobil eszközökön is elérhetök legyenek.

- digitális tananyagtár

A tananyagtár olyan - az aktuális képzéseket támogató - gyüjtemény, amely biztositja az interaktív, multimédiás tananyagok, tanulási elemek és objektumok szabványos módon történő feltöltését, feldolgozását (Dublin Core és/vagy LOM alapú leíró adatok hozzárendelését), kereshetőségét és használatát. 


\section{Multimédiás tananyag}

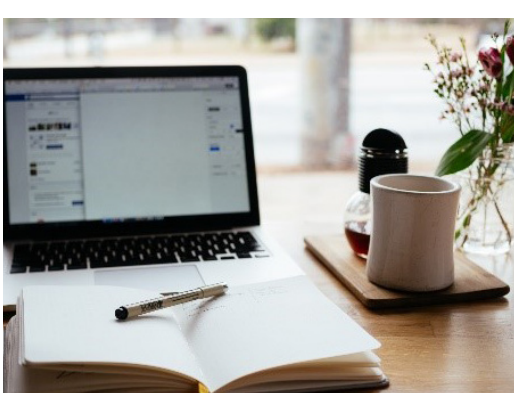

A közbeszerzés során a multimédiás tananyagok kialakitására többen is pályáztak, a nyertes pályázó az OnlearnTech Kft. lett. A fejlesztés során négy tananyag születik meg, amelyek a késöbbiekben blended képzésekbe épülnek be. (témakörök: webarchiválás, állományvédelem, digitalizálás, az e-learning módszertana, szerzői jogi tudnivalók az elektronikus tananyag használatáról)

Mielőtt azonban a fejlesztés lépéseit röviden bemutatnám, szeretném fogalommeghatározással kezdeni. Ezen a területen is különbözö megvalósitási formákba, típusokba botlottunk, ezért a magunk számára így értelmeztük az elektronikus tananyag fogalmát:

Olyan pedagógiai elvek alapján, az informatika eszközeivel felépitett oktatási tartalom, amely önálló, módszertani szempontból zárt egységet alkot, de akár egy vagy több képzéshez is illeszkedhet. Felépítését és alkotóelemeit szabvány rendszerezi. Alapvető célja egy adott kompetencia kialakitása, fejlesztése.

A fejlesztés során az a célunk, hogy weben elérhetö, a könyvtári szakmai továbbképzést támogató, szabványos, multimédiás, interaktiv tananyagok készüljenek, amelyek internetes böngészőkben, mobil eszközökön és egy nyilt szabványokat és open source megoldásokat támogató rendszerben is lejátszhatók, megtekinthetök.

\section{Általános formai elvárásaink a multimédiás tananyaggal szemben}

Egységes, a tartalomhoz illö design, amely felhasználóbarát és könnyen kezelhetö Egységes megjelenés, témakörök szerinti színválasztás. Felhasználóbarát, menürendszere átlátható és könnyen kezelhető, a navigálás egyszerü. A szép design a felhasználó számára eszköz, amely segiti a tartalom megtalálásában (pl. egyértelmü ikonok segitségével).

\section{Szabványos megoldásokat alkalmaz (pl.: HTML5, SCORM)}

Egy jól müködő elektronikus tananyag alapja az e-learning szabványok használata, ezek biztositják a tananyagok megtekinthetőségét, lejátszhatóságát és kereshetöségét a különböző típusú, tanulási folyamatokat menedzselő rendszerekben. Az ily módon elkészitett tananyagok elemei, objektumai újrahasznosithatók egy új képzés kialakitása során. A legismertebb e-learning szabvány a SCORM, amelynek több verziója is napvilágot látott már.

\section{Interaktiv elemeket tartalmaz}

Az interaktív elemek kiegészitik a szöveges tananyagot, segitik és támogatják a tanulás hatékony megvalósulását. Egyszerü, játékos, interaktív megoldás lehet pl. drag and drop tesztek használata. A teljesitmények elismerésének az egyik formája lehet pl. kitüzők (badges) adása. 
Reszponziv megjelenitést biztosit

A felhasználói élmény biztositása, a tananyagok jó olvashatósága, hordozhatósága, lejátszhatósága okos eszközökön (pl:: okostelefon, tablet) elengedhetetlen. A reszponzív megjelenítés jellemzöje, hogy eszközfüggetlenül, rugalmasan alkalmazkodik a böngészők felületéhez azért, hogy optimális megjelenést adjon. Szabványa a HTML5-t kiegészitő CSS3.

\section{A tananyagok felépítése}

A tananyagok felépítése moduláris. Az egy modulba tartozó leckék jellemzője, hogy közöttük tartalmi-logikai kapcsolat van.

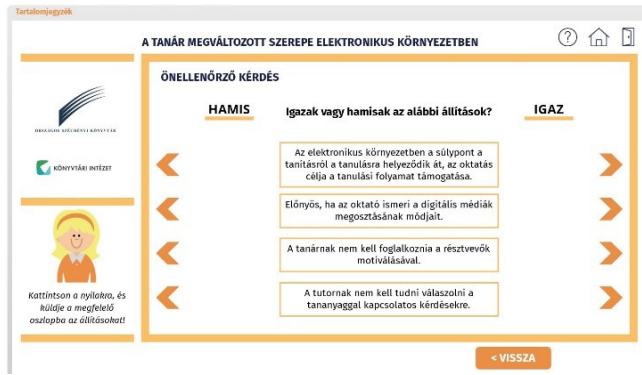

A fejlesztés folyamata

A modulok elején rövid bevezető található, amely leirja, hogy mi az adott modul célja és tartalma, milyen kompetenciákat fejleszt.

A modulok végén - a lényeges információk kiemelésével - rövid összefoglalást és önellenörző kérdéseket, feladatokat helyeztünk el, amelyek segitségével a képzésben résztvevők ellenörizhetik a tudásukat az adott modul témájában. A helyes válaszok azonnal megtekinthetők.

A multimédiás tananyag tervezésekor meghatározott célrendszer rögzitése után és arra épülve készittettük el a kéziratokat az adott téma szakértöivel.

A kéziratírás során jött létre az az oktatási tartalom, amellyel a továbbiakban a tananyagfejlesztők dolgoztak. Ez tekintjük a végleges tananyag háttéranyagának, szakmai dokumentációjának. (A teljes kéziratot az egyes moduloknál letölthetövé tettük.)

Ez az oktatási tartalom alakul tovább, ebben a formában még nem rendelkezik az online tananyagok jellemzőivel, lineáris és statikus. Ebben a fázisban már együtt dolgoztunk a szerzökkel és a fejlesztőkkel. Közösen emeltük ki a lényeges gondolatokat, az alapfogalmakat és minden olyan tanulási egységet, amely a tananyag sikeres elöállításához és használatához tartozik.

Ebben a fázisban gondoskodtunk azoknak az elemeknek a megtervezéséről is, amelyek az oktatási tartalmat kiegészitik, illusztrálják (pl.: kép, videó, animáció, hanganyag, design elemek).

A következö lépésként elkészültek a forgatókönyvek, amelyek tükrözik a kézirat szerkezeti felépitését, de azon túlmutatnak a didaktikai elemek beépitésével. Elkészitésük során jött létre a végleges tartalom és a médiaelemek listája, egy adott szerzői rendszerre specializálódva. A digitális tananyag összeállitása a forgatókönyvben található szövegek, módszertani elemek és multimédia állományok jelölése alapján, azok pontos meghatározásával történt. 
Az elektronikus tananyag tervezési folyamatában a forgatókönyv elkészitéséhez prototípusokat alakitottunk ki a fejlesztőkkel, amelyek támogatják a szöveg egységes megjelenését, stílusát és az oktatási tartalom tagolását.

A fejlesztők az elkészült tananyagokat úgy adják át, hogy lehetőségünk legyen a későbbiek során a tartalmak átdolgozására, frissitésére.

A tananyag tesztelésébe a kéziratok szerzőit is bevontuk, velük együttmüködve, véleményük, javaslatuk alapján végezzük el a módositásokat, változtatásokat. A végső változatnak stilisztikai, müfaji és müködési szempontból kifogástalannak, hibátlannak kell lennie.

\section{Folyamatban lévő tananyagfejlesztések}

A Könyvtári Intézet módszertani vezetésével a szakmai továbbképzésekhez további témákat választottunk ki, amelyekröl szakértők bevonásával 20 db kézirat készült el.

Multimédiás tananyaggá alakitásukhoz jelenleg forrást keresünk.

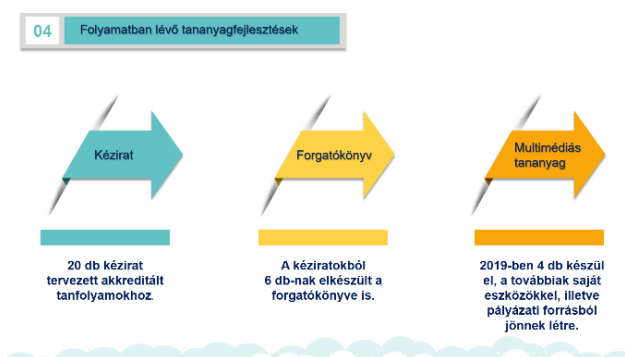

\section{Képzők képzése}

A Könyvtári Intézet oktatóit és a projektben fejlesztés alatt álló tananyagok szerzőit egy rövid képzés során készitettük fel a kéziratok megírására.

A képzés célja, hogy a résztvevök a tananyag elsajátítása során megismerjék az e-learning és az elektronikus tananyag fogalomrendszerét, felépitését, képesek legyenek arra, hogy - saját témakörükhöz - önállóan létrehozzák egy elektronikus tananyag kéziratát, valamint tanácsadóként részt vegyenek az e-learning oktatási tartalom kialakitásában.

A projektünk az OKR fejlesztéssel is kapcsolatban van, ezért a késöbbiek során az ott jelentkező oktatási igényeket is figyelembe vesszük, illetve a partner könyvtárakban dolgozó kollégákat is igyekszünk felkésziteni a rendszerünk használatára, valamint elektronikus tananyagok készitésére.

A képzések további célja a szemléletváltás támogatása, a szakmai kompetenciák fejlesztése és új ismeretek átadása.

\section{A multimédiás tananyagok helye és szerepe a továbbképzésben Online oktatás}

Munkánk során több alkalommal is belefutottunk abba, hogy az online tanulási és oktatási környezet meghatározása mennyire sokszinü. Az online oktatásmódszertan esetében mégtöbb változatot és lehetőséget tapasztaltunk, ezek közül pár fogalmat emelnék ki: távoktatás, e-learning, blended learning, online oktatás, 
konnektivizmus. A meghatározásokat tovább árnyalhatja az, hogy melyik szakmán belül használják.

Számunkra - meghatározása és felhasználási módja miatt -- a mai magyarországi tanulási és oktatási módszerek közül a blended learning látszik legmegfelelőbbnek. A "kevert képzés" olyan oktatásmódszertani megoldás, amely egymásba integrálja a kontakt tevékenységeket az online tevékenységekkel, az irányított tanulást az önszabályozó tanulással, vagyis az online oktatást a jelenléti oktatás kiegészitéseként értelmeztük.

Ennek fényében a kontakt (gyakorlat) tevékenységek részben változatlan formában maradnak (tartalmi és módszertani szempontból), de az órák egy része helyettesithető online elérhető, multimédiás tananyagokkal, amelyek kiegészítik a jelenléti oktatást és többlet ismeretet adnak át. (információk, tudásanyagok, tesztek, feladatok stb.).

\section{Összefoglalás}

A Könyvtári Intézet - azon belül az Oktatási és Humánerőforrás-fejlesztési osztály -olyan oktatást támogató rendszer létrehozását tervezi, amely eszközöket biztosít az oktatásszervezéshez, támogatja az oktatási és tanulási tevékenységet és szabványos környezetet biztosít az elektronikus tananyagok szolgáltatásához, lejátszásához, tárolásához.

\section{Bibliográfia}

ANTAL Péter: Interaktív elektronikus tananyagok tervezése. Eger, Eszterházy Károly Föiskola, 2013. 175 p. (Médiainformatikai kiadványok)

Islam, Md. Shiful: How library and information science academic administrators perceive e-learning in LIS schools : a qualitative analysis. In: IFLA journal. - 40. (2014) 4., 254-266 p.

Kane, Kathryn: Tapping into social networking: collaborating enhances both knowledge management and e-learning. In: VINE. - 40. (2010) 1., 62-70p.

Komenczi Bertalan: Az E-learning lehetséges szerepe a magyarországi felnőttképzésben. Bp., Nemzeti Felnőttképzési Intézet, 2006. 60p.

Nagy Vitéz: „E-learning ABC”. In: Vezetéstudomány, 2016. XLVII. Évf. 12. szám, 6-15p.

Noesgaard, S. S. es Orngreen, R. es Foundation, K.: The Effectiveness of E-Learning : An Explorative and Integrative Review of the Definitions, Methodologies and Factors that Promote e-Learning Effectiveness. In: Electronic Journal of e-Learning, 13. volume, 2015. p. 278-290.

OKTATÁSTERVEZÉS, digitális tartalomfejlesztés. Szerk.: Ollé János, Kocsis Ágnes, Molnár Elöd. Eger : Liceum K., 2015. 266 p 